\title{
SCIENTISTS TRIO WERE CRAZY FOR CHIMPANZEE INTENDED TO SEE HEPATITIS C: WISE FOR NOBEL PRIZE
}

\author{
TAPAS GOSWAMI ${ }^{1}$
}

${ }^{1}$ Former Principal Scientist, Immunology Section, Indian Veterinary Research Institute, Izatnagar243 122, Uttar Pradesh, India

\section{Hepatitis a global crisis}

In 2020 the Nobel prize in the field of medical sciences (Physiology or Medicine) has been awarded jointly to three eminent scientists for their contribution towards hepatitis virus research.The unprecedented infectious hepatitis kills more than one million people worldwide every year. Evidence of the disease has been found in Biblical texts dating back to $400 \mathrm{BC}$. Long before the causative agent for human hepatitis was known to scientific community, one of the British physicians proposed a classification of infectious hepatitis into two types (i) hepatitis A and (ii) hepatitis B based upon the mode of transmission and clinical courses of disease (MacCallum, 1947).

\section{Why did they win?}

Since 1963 the hepatitis B virus has entered the laboratory of peer group of scientific community as priority area of research. During press release event on $5^{\text {th }}$ October 2020 Nobel committee at Karolinska Institute in Stockholm declared the Nobel Prize in Physiology and Medicine for the year 2020 with a statement that "For the first time in history, the disease can now be cured, raising hopes of eradicating hepatitis $\mathrm{C}$ virus from the world population" (Prize announcement, 2020). The discovery of the hepatitis $\mathrm{C}$ virus has solved a scientific mystery for the physicians and researchers, which remained baffling for years together. Due to technological development effective vaccine against hepatitis A and hepatitis B are widely available across the globe but not yet for hepatitis $\mathrm{C}$. The detection of the hepatitis $\mathrm{C}$ virus has made it easier to find new drugs with blood tests that have saved millions of lives. Once scientific community could not detect the hepatitis virus in any other available animal species obviously, scientists were crazy for chimpanzee as last resort. Fortunately, it is the only animal susceptible to hepatitis virus. Lack of animal model was a limiting factor in progress of hepatitis virus research, therefore, the decision to experimentally infect the chimpanzee for hepatitis $\mathrm{C}$ virus as a model was wise decision that eased for the prize nomination.

\section{Who are the winners?}

The researchers who identified and described hepatitis $\mathrm{C}$ virus the prime causative agent for bloodborn hepatitis in human are Harvey James Alter, of the National Institute of Health in Harvey James Alter Bethesda, Maryland, USA. He was born in New York in 1935.Alter received a bachelor's degree (1960) in medical science from 
Rochester Medical School; he joined the National Institutes of Health (NIH) in 1961. From his lab first major breakthrough came while working with Blumberg at NIH, in early 1960s, identified a surface antigen on hepatitis $B$ virus specifically reactive with serum from Australian aborigine and haemophilic patient.The newly identified antigen was detectable in about 11 percent of American leukemic patients and a very small percentage of healthy Americans were reactive towards this antigen. Subsequently this antigenic protein was designated as Australian antigen (AuAg). By 1967 accumulated evidence showed a strong corelation between the presence of $\mathrm{AuAg}$ and viral hepatitis. Alter designed an assay to detect the viral antigen, named $\mathrm{HBsAg}$, in donor blood. The later development of a highly sensitive method of HBsAg detection in donor blood led to a dramatic decrease in transfusionassociated hepatitis. Alter was serious to detect the hidden cause of blood transfusion related hepatitis. In the mid-1980s Alter advised blood banks to test hepatitis B core antibody (anti$\mathrm{HBc}$ ) in blood samples, as a proxy marker for non-A, non-B hepatitis virus.

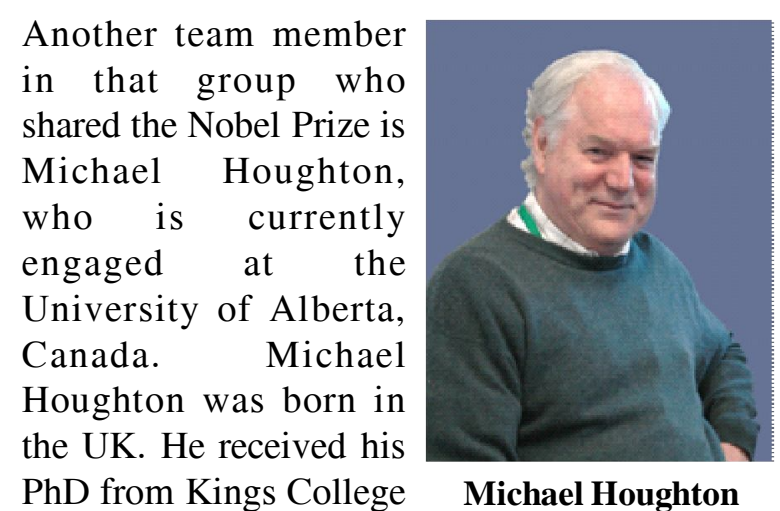
London in 1977. He has been working as a virus expert at Alberta University since 2010. Houghton and his two co-workers were exploring the possibility of an animal model to reproduce the hepatitis disease for which they infected chimpanzees with serum from a patient diagnosed with hepatitis of unknown reason. From the plasma of experimental chimpanzee named No 910; DNA and RNA were extracted, for production of virus specific recombinant protein using lambda phage and $E$ coli expression vector. Interestingly the serum from hepatitis patient was reactive to this new designed protein indicated the existence of a new virus on those patients.

Next in that series is Charles Moen Rice born in 1952 in Sacramento, USA is currently working at Rockefeller University in New York City. He received his $\mathrm{PhD}$ from the California Institute of Technology in 1911. Charles Rice

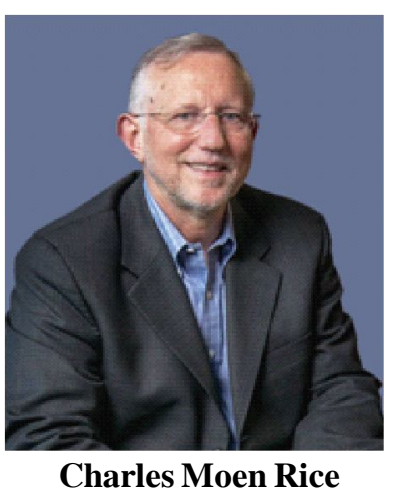
was the Executive Director (2011-2018), holding a key position at Rockefeller University, Centre for Hepatitis-C studies. Their data on the hepatitis $\mathrm{C}$ virus are considered to be a guide for effective treatment. During his graduate course Rice worked on mosquitoes borne Sindbis virus, responsible for fever and joint pain in humans. His interest on yellow fever virus genome led to the establishment of the flavivirus family. In the late 1980s he shifted his research on hepatitis $\mathrm{C}$ for vaccine development. Rice later discovered that a portion of the hepatitis $\mathrm{C}$ virus (HCV) genome necessary for viral replication was missing in the laboratory HCV clone. In 1996 he provided a description of the complete $\mathrm{HCV}$ genome (Kolykhalov et al., 1996).

\section{Hepatitis virus}

Since 1990s it has been clearly shown that hepatitis is mainly caused by two different types of viruses (Choo et al., 1989). The type one is called hepatitis A, which is transmitted through contaminated water or food, and its side effects are usually short-lived. The second type of virus, hepatitis $\mathrm{B}$, is transmitted by blood and body fluids, which can lead to complications such as cirrhosis and liver cancer. According to the type of hepatitis virus they are classified as A, B, C, D, and E. Hepatitis A is transmitted by 
contaminated faeces from infected persons through food and water, hepatitis B and C through exposure of infected blood, hepatitis $\mathrm{D}$ infection occurs only in those who have been infected with hepatitis B (the dual infection), hepatitis $\mathrm{E}$ is also due to contaminated food and water. The hepatitis B virus is under the DNA group of viruses while it is RNA for hepatitis A, C, D and E. Hepatitis virus mainly prefers liver cells as their shelter and site of multiplication, resulting destruction of liver cell add leads to grave consequence. Ultimately the liver function is ceased and the affected patients gradually succumb.

\section{Search for mysterious slayer}

In the early 1980s, most people who received blood from the blood bank were suffering from an unknown, mysterious liver disease, which was a major concern. Scientific publication indicates that as early as in 1965 Baruch Blumberg was the first to provide evidence of transmission of hepatitis through blood (Blumberg et al., 1965). Subsequently the causative agent for hepatitis was confirmed to be hepatitis B virus with scientific evidence, for which Baruch Samuel Blumberg received Nobel Prize in 1976. It is noteworthy that the hepatitis B virus, which is transmitted by blood, is more likely to be transmitted through blood donors or stored blood in the blood banks. In addition, re-use of needles and syringes in health care centres and hospitals has the potential to spread the disease. Despite the extreme caution and proper blood tests, no significant change in the number of patients with the disease was observed, which was adequate to accept that hepatitis $\mathrm{A}$ was not the prime culprit for the unexplained cases (Feinstone et al., 1975). It was a puzzle for medical fraternity and the search was not easy either.

\section{Alter's involvement}

Alter published a ground-breaking piece of information from his one-on-one experiment, in which he established with authenticity that hepatitis virus can infect chimpanzee the only susceptible species other than human (Alter et al., 1978). This information has made it possible to find the virus that causes the disease. In his opinion, it is a different kind of virus so the virus was designated as non-A, non-B (Alter et al., 1975).

\section{Houghton contribution}

Houghton, in collaboration with his co-workers Qui-Lim Choo and George Kuo, could able to isolate the genetic sequence of a new virus with unproven experimental approach from the blood sample collected from some of the infected chimpanzees (Choo et al., 1989). They speculated that the presence of new virus might be the major culprit for dissemination of hepatitis within population. The study found that although these genetic constituents were related to virus from chimpanzees, there were some addition or deletion regions and few inconsistencies in some cases. He predicted that these incompatible gene fragments could have originated from an unknown viral gene. To rule out the possibility of error, he collected blood from some hepatitis patients and found that the antibodies (immunoglobulin) in the patient's serum were sensitive and specifically reactive to the above incompatible genome-specific protein (Choo et al., 1989). As consensus aroused among scientific group the virus was finally designated as hepatitis $\mathrm{C}$ virus.

\section{Wise device by Rice}

Even though the discovery of new hepatitis virus genetic sequence was crucial; yet only viral genomic regions were unable to produce complete matured infective virus particle, so an important part was missing to establish the viral existence. The search for the missing link was carried out by Charles Rice for which he has been recognised to share the honour and prize money. In the next step using a unique process, Charles Rice was able to modify the genetic segment in his laboratory to a new design, rendering it potentially viable and suitable for intracellular multiplication. As a result, it 
acquired infectivity along with competence for transmission. Infusing the modified genome in the liver of a chimpanzee they were able to reproduce the disease experimentally with clinical symptoms (Kolykhalov et al., 1997).

\section{Significance of the discovery}

As per WHO, global hepatitis report nearly 72 million people across the world are living with chronic hepatitis C infection as on 2015 (WHO, 2017). Many patients harbour the virus as carrier of hepatitis $C$, unaware that they have been infected with the virus. Unless the disease is diagnosed clearly and timely, treatment is not provided and can lead to chronic hepatitis. Chronic hepatitis may not always respond to therapy rather patients may need liver transplants. As transplantation cost is plenty along with availability of organ being scanty, it heightens the mortality curve to worrying situation. Due to proper blood testing strategy in several countries, the number of hepatitis B virus infections is nearly zero. Underdeveloped countries, where the test rate is less than $10 \%$, more specifically the low-income population is deprived of the right diagnosis, so they are the major victim.

\section{Recent therapy}

Few drugs such as beceprevir, teleprevir and simeprevir, that inhibit the NS3/NS4 (NS nonstructural) proteases of hepatitis C virus, essential for viral replication in cell culture and chimpanzee has been targeted as antiviral therapy (Strader et al., 2004). Current treatment is a combination therapy of pegylated IFN- $\alpha$ (IFN conjugated with polyethylene glycol with long half-life) and oral dose of ribavirin results in clearance of hepatitis C viral RNA from patients' serum (Fried et al., 2002). Due to advancement in science direct acting antiviral

\section{REFERENCES}

Alter HJ, Holland PV, Morrow AG, Purcell RH, Feinstone SM et al., 1975. Clinical and serological analysis of transfusion-associated hepatitis. Lancet, 2(7940): 838-841, doi: 10.1016/ s0140-6736(75)90234-2
(DAA) without use of interferon has transformed the treatment module with higher cure rate. Although the DAA has improved the situation, the hepatitis has not been eliminated due to reinfection (Bailey et al., 2019).

\section{For better days}

Presently vaccines are available to prevent hepatitis A and hepatitis B disease, but vaccine for hepatitis $\mathrm{C}$ is yet to arrive. Major challenge for vaccine development against hepatitis $\mathrm{C}$ is the extraordinary genetic diversity of the virus having seven major genotypes with 67 subtypes.Therefore, designing a lonely vaccine "fit for all" approach to generate protective antibody is difficult to achieve. Recent studies demonstrated that due to immune pressure, antibody resistance variant of hepatitis $\mathrm{C}$ virus has aroused due to additional mutation that can dodge the immune mechanism (Smith et al., 2014). Nearly $25 \%$ of acute hepatitis C infection population, there is spontaneous virus clearance but may get re-infection; in both the situation there is lack of sterilizing immunity, demanding effective vaccine. Recently virus like particle has been designed (VLP) as vaccine candidate comprising of E1 \& E2 (E-envelop protein), core protein as well as non-structural protein of hepatitis $\mathrm{C}$ virus amalgamated with adjuvant. Antibody response generated with this vaccine is adequate yet not protective in chimpanzee model (Elmowalid et al., 2007). At present situation in chronic patients' vaccine along with antiviral drug may be beneficial. Michael Houghton and several other researchers across the world are breaking their head to develop vaccine against hepatitis $C$, yet possibility of success is remote (Houghton, 2011). Hopefully if the vaccine will induce protective immunity, it will be easier to prevent hepatitis $\mathrm{C}$ related infections in the future.

Alter HJ, Purcell RH, Holland PV and Popper H, 1978. Transmissible agent in non-A, non-B hepatitis. Lancet 1(8062): 459-463, doi: 10.1016/s0140-6736(78)90131-9 
Bailey JR, Barnes E and Cox AL, 2019. Approaches, progress, and challenges to hepatitis $\mathrm{C}$ vaccine development. Gastroenterology, 156(2): 418-430, doi: $10.1053 /$ j.gastro.2018.08.060

Blumberg BS, Alter HJ and Visnich S, 1965. A "new" antigen in leukemia sera. JAMA, 191: 541-546, doi: 10.1001/jama.1965.03080070025007

Choo QL, Kuo G, Weiner AJ, Overby LR, Bradley DW et al., 1989. Isolation of a cDNA clone derived from a blood-borne non-A, non-B viral hepatitis genome. Science, 244(4902): 359-362, doi: $10.1126 /$ science. 2523562

Elmowalid GA, Qiao M, Jeong SH, Borg BB, Baumert TF et al., 2007. Immunization with hepatitis C virus-like particles results in control of hepatitis $\mathrm{C}$ virus infection in chimpanzees. Proc NatlAcad Sci, 104(20): 8427-8432, doi: 10.1073/ pnas.0702162104

Feinstone SM, Kapikian AZ, Purcell RH, Alter HJ and Holland PV, 1975. Transfusion-associated hepatitis not due to viral hepatitis type A or B. N Engl J Med, 292(15): 767-770, doi: 10.1056/ NEJM197504102921502

Fried MW, Shiffman ML, Reddy KR, Smith C, Marinos $\mathrm{G}$ et al., 2002. Peginterferon alfa-2a plus ribavirin for chronic hepatitis $\mathrm{C}$ virus infection. $\mathrm{N}$ Engl J Med, 347(13): 975-982, doi: 10.1056/ NEJMoa020047

Houghton M, 2011. Prospects for prophylactic and therapeutic vaccines against the hepatitis $\mathrm{C}$ viruses. Immunol Rev, 239(1): 99-108, doi:

$$
\text { 10.1111/j.1600-065X.2010.00977.x }
$$

Kolykhalov AA, Feinstone SM and Rice CM, 1996. Identification of a highly conserved sequence element at the $3^{\prime}$ terminus of hepatitis $\mathrm{C}$ virus genome RNA. J Virol, 70(6): 3363-3371, doi: 10.1128/JVI.70.6.3363-3371.1996

Kolykhalov AA, Agapov EV, Blight KJ, Mihalik K, Feinstone SM et al., 1997. Transmission of hepatitis $\mathrm{C}$ by intrahepatic inoculation with transcribed RNA. Science, 277(5325): 570-574, doi: $10.1126 /$ science.277.5325.570

MacCallum FO, 1947. Homologous serum jaundice. Lancet, 2: 691-692

Prize announcement. NobelPrize.org. Nobel Media AB 2020. 17 Nov 2020, https://www.nobelprize.org/ prizes/medicine/2020/prize-announcement

Smith DB, Bukh J, Kuiken C, Muerhoff SA, Rice CM et al., 2014. Expanded classification of hepatitis $\mathrm{C}$ virus into 7 genotypes and 67 subtypes: updated criteria and genotype assignment web resource. Hepatology, 59(1):318-327, doi: 10.1002/ hep. 26744

Strader DB, Wright T, Thomas DL and Seeff LB, 2004. Diagnosis, management, and treatment of hepatitis C. Hepatology, 39(4): 1147-1171, doi: 10.1002/hep.20119

WHO, 2017. Global Hepatitis Report. https:// wwwwhoint/hepatitis/publications/globalhepatitisreport2017/en/external $2017 \quad$ [5 November 2020] 